\title{
Editorial: Interactive Feedbacks Between Soil Fauna and Soil Processes
}

\author{
Maria L. Cayuela ${ }^{1 *}$, Julia Clause ${ }^{2}$, Jan Frouz ${ }^{3}$ and Philippe C. Baveye ${ }^{4}$ \\ ${ }^{1}$ Department of Soil and Water Conservation and Waste Management, Center for Edaphology and Applied Biology of \\ Segura, Spanish National Research Council, Espinardo, Spain, ${ }^{2}$ Laboratoire Ecologie Biologie des Interactions, Université de \\ Poitiers, UMR CNRS 7267, Poitiers, France, ${ }^{3}$ Charles University, Prague, Czechia, ${ }^{4}$ UMR Ecosys, AgroParisTech, Université \\ Paris-Saclay, Paris, France
}

Keywords: soil functions, earthworms, Collembola, macrofauna, soil biodiversity

\section{Editorial on the Research Topic}

\section{Interactive Feedbacks Between Soil Fauna and Soil Processes}

Soil fauna plays a significant role at all trophic levels of the soil food web and regulates processes that are crucial for soil functioning, such as nutrient cycling, immobilization and/or degradation of toxic compounds, formation of soil structure, greenhouse gas emissions, and C turnover. Yet,

\section{OPEN ACCESS}

Edited by:

Dionisios Gasparatos,

Aristotle University of

Thessaloniki, Greece

Reviewed by:

Constantinos Ehaliotis, Agricultural University of

Athens, Greece

*Correspondence:

Maria L. Cayuela

mlcayuela@cebas.csic.es

Specialty section:

This article was submitted to

Soil Processes,

a section of the journal

Frontiers in Environmental Science

Received: 09 December 2019

Accepted: 27 January 2020

Published: 10 March 2020

Citation:

Cayuela ML, Clause J, Frouz J and Baveye PC (2020) Editorial: Interactive

Feedbacks Between Soil Fauna and

Soil Processes.

Front. Environ. Sci. 8:14.

doi: 10.3389/fenvs.2020.00014 the functional contribution of soil fauna to many soil processes is not well-understood due to methodological limitations and the high complexity of interactions at various spatiotemporal scales (Briones, 2014; Frouz, 2018). For example, some effect such as aggregate formation may cumulate over time and finally contribute to the formation of whole soil profiles, which serve as a framework for other soil processes such as water movement, decomposition, etc. This complexity can only be disentangled through multidisciplinary efforts, which to this day have remained a major challenge.

In spite of its relevance, soil fauna has received far less scientific attention than bacteria and fungi (and lately archaea) in soil studies and has been regularly ignored in global biogeochemical models, the only exception, to some extent, being earthworms (Blouin et al., 2013; Briones, 2014; Grandy et al., 2016). However, recent studies are raising awareness of the influence of soil fauna on ecosystem dynamics (Filser et al., 2016). For instance, earthworms exert a strong influence on C stabilization (Frouz, 2018), and they promote the degradation of organic contaminants, such as PAHs or PCBs (Hickman and Reid, 2008). In laboratory studies, they have been found to be major players in $\mathrm{N}_{2} \mathrm{O}$ emissions from soils (Lubbers et al., 2013) although their impact under field conditions remains practically unknown (MOU KEYSOME, 2014). Less studied, ants and termites have been found to increase crop productivity in drylands (Evans et al., 2011), and different lifeforms of Collembola have been shown to impact microorganisms in various ways over time, thereby potentially affecting $\mathrm{C}$ and $\mathrm{N}$ cycles within farming systems (Filser, 2002). Recently, the role of soil fauna on root-associated microbiome and its interactions with plants has rapidly emerged as a potential new field of research, which is still practically unexplored.

In this general context of potentially extremely relevant, yet very much downplayed, effects of soil fauna on a wide range of soil processes, we believe that this Research Topic makes significant contributions to the current literature. It gathers a collection of studies that investigate (or reflect on) the interactive feedbacks between soil fauna and soil processes, and it also addresses the question of how the increasing human pressure affects soil fauna biodiversity, with associated consequences on soil functioning and resilience. A total of eight articles have been published, including two reviews and six original research articles. 
In the first review, Briones reflects on the intrinsic difficulties encountered when describing and classifying soil biodiversity, and on the necessity to expand our knowledge about the interactions between soil fauna, soil microorganisms, and plant roots. She critically examines novel concepts arising in soil fauna research and proposes to redirect the focus toward advanced experimental ideas in order to better understand the complex interactions between soil fauna and soil processes.

Earthworms are, by far, the most studied organisms from all soil fauna and the review by Medina-Sauza et al. synthetizes the current knowledge about their influence on the structure and function of soil microbial communities, and how this indirectly affects soil processes in the rhizosphere. The study pays special attention to the effect of earthworms on signal molecules promoting plant growth.

Two of the original research articles focus on earthworms. In a state-of-the-art mesocosm study, Vidal et al. combine advanced spectroscopic techniques (TEM, NanoSIMS) with classical, robust bulk measurements (13C-CPMAS-NMR and EA-IRMS) to follow the fate of $\mathrm{C}$ from plant residues to earthworm casts. They clearly demonstrate the role of earthworms in the formation of organo-mineral associated organic matter in soil. The second article on earthworms describes a field study in Ivory Coast, where Tondoh et al. investigate the role of earthworms on soil health changes over a 25-year chronosequence from forest to rubber tree plantations. Surprisingly, they show no statistical differences in soil physical characteristics, soil organic carbon, earthworm density, species richness and soil health indices between forest and longstanding ( $>12$ years) rubber tree plantations, which suggests a restorative trend after the initial soil health deterioration.

Macrofauna (earthworms, termites, ants, beetles) are important agents of bioturbation in soils. Their foraging and burrowing activities modify soil physical structure, which impacts relevant soil functions, such as water infiltration and retention, gas exchange and soil organic matter dynamics (Bottinelli et al., 2015). In a fascinating study, Cheik et al. use $\mathrm{X}$-ray computed tomography to quantify soil macroporosity and relate it to soil saturated hydraulic conductivity in a sloping area in northern Vietnam. Their study shows that X-ray CT is a promising tool to quantify macroporosity in soil and verifies

\section{REFERENCES}

Blouin, M., Hodson, M. E., Delgado, E. A., Baker, G., Brussaard, L., Butt, K. R., et al. (2013). A review of earthworm impact on soil function and ecosystem services. Eur. J. Soil Sci. 64, 161-182. doi: 10.1111/ejss.12025

Bottinelli, N., Jouquet, P., Capowiez, Y., Podwojewski, P., Grimaldi, M., and Peng, X. (2015). Why is the influence of soil macrofauna on soil structure only considered by soil ecologists? Soil Tillage Res. 146, 118-124. doi: 10.1016/j.still.2014.01.007

Briones, M. J. I. (2014). Soil fauna and soil functions: a jigsaw puzzle. Front. Environ. Sci. 2:7. doi: 10.3389/fenvs.2014.00007 the positive impact of soil fauna on water infiltration. They also demonstrate that aboveground biostructures and macropore properties are not necessarily related.

Two articles focus on Collembola. In an original contribution, Menta et al. investigate the feeding preferences of springtails, which were offered a choice between 12 different species of truffle. The study demonstrates the ease of springtails to modify their feeding habits, and it also shows that natural feeding preferences do not always lead to the best fitness (in terms of survival and reproduction at least in the short term). In a second inspiring article, Coulibaly et al. examine how two natural assemblages of Collembola affect microbial communities using PLFA markers, enzyme activities and $\mathrm{C}$ mineralization rate. They demonstrate that the influence of Collembola differs depending on their ecological traits, with varying effects on microbial community abundance, structure, and activity.

The last manuscript, a very comprehensive study by Ayuke et al., shows empirical evidence of the benefits of conservation agriculture on soil fauna diversity in three field trials in Kenya. At a time when anthropogenic pressure through deforestation, agriculture intensification, habitat fragmentation, and climate change threatens soil biodiversity, the experimental work presented by these authors should help bridge the gap between agro-ecological principles and practical agronomic applications, hopefully paving the way for a transition toward biodiversitypromoting agriculture.

We hope this Research Topic will stand as a small but solid and appreciated contribution to the field of soil biodiversity and that the articles published will be supportive and stimulating not only to researchers interested in this field, but also to others who may not have been particularly sensitive until now to the very significant role played by soil fauna in a wide variety of soil processes. Finally, we are very thankful to all the authors who submitted their manuscripts for consideration in this Research Topic, as well as all the reviewers for their efforts, which certainly improved the quality of the manuscripts.

\section{AUTHOR CONTRIBUTIONS}

MC and PB drafted a first version of this editorial. All authors contributed to and approved the final version. 
Frouz, J. (2018). Effects of soil macro- and mesofauna on litter decomposition and soil organic matter stabilization. Geoderma 332, 161-172. doi: 10.1016/j.geoderma.2017.08.039

Grandy, A. S., Wieder, W. R., Wickings, K., and Kyker-Snowman, E. (2016). Beyond microbes: are fauna the next frontier in soil biogeochemical models? Soil Biol. Biochem. 102, 40-44. doi: 10.1016/j.soilbio.2016.08.008

Hickman, Z. A., and Reid, B. J. (2008). Earthworm assisted bioremediation of organic contaminants. Environ. Int. 34, 1072-1081. doi: 10.1016/j.envint.2008.02.013

Lubbers, I. M., van Groenigen, K. J., Fonte, S. J., Six, J., Brussaard, L., and van Groenigen, J. W. (2013). Greenhouse-gas emissions from soils increased by earthworms. Nat. Clim. Change 3, 187-194. doi: 10.1038/nclimate1692

MOU KEYSOME (2014). Memorandum of Understanding for the Implementation of a European Concerted Research Action designated as COST Action ES1406:
Soil fauna - Key to Soil Organic Matter Dynamics and Modelling (KEYSOM). Available online at: http://www.keysom.eu/posts/mou

Conflict of Interest: The authors declare that the research was conducted in the absence of any commercial or financial relationships that could be construed as a potential conflict of interest.

Copyright (c) 2020 Cayuela, Clause, Frouz and Baveye. This is an open-access article distributed under the terms of the Creative Commons Attribution License (CC BY).

The use, distribution or reproduction in other forums is permitted, provided the original author(s) and the copyright owner(s) are credited and that the original publication in this journal is cited, in accordance with accepted academic practice. No use, distribution or reproduction is permitted which does not comply with these terms. 